\title{
PERSEPSI MASYARAKAT TERHADAP FAKTOR PENDUKUNG SEKRETARIS DESA DALAM MEMBERIKAN PELAYANAN DI BIDANG ADMINISTRASI.
}

\author{
Daniel Parubang ${ }^{(1)}$, Haspidawati Nur ${ }^{(2)}$, Jusrianto ${ }^{(3)}$, Hasnita ${ }^{(4)}$
}

\begin{abstract}
DanielP@yahoo.com, Haspidwatinur19@gmail.com, Jusriantoppsunj@yahoo.com.
\end{abstract}
\begin{abstract}
ABSTRAK
Tujuan penelitian ini adalah untuk mengetahui Persepsi Masyarakat Terhadap Peranan Sekretaris Desa dalam Memberikan Pelayanan di Bidang Administrasi di Desa Buntu Awo Kabupaten Luwu. Dalam melakukan penelitian ini penulis menggunakan jenis penelitian deskriptif kuantitatif. Jumlah sampel yang diambil sebanyak 30 orang menggunakan teknik simple random sampling. Teknik pengumpulan data menggunakan teknik observasi, dokumentasi dan angket. Hasil penelitian menunjukkan persepsi masyarakat terhadap Faktor yang yang mendukung peranan sekretaris desa dalam memberikan pelayanan di bidang administrasi di Desa Buntu Awo Kabupaten Luwu berada. Hal ini terlihat dari jawaban responden sebanyak 45,3\% menyatakan sangat setuju, 34\% setuju dan sebanyak 20,7\% menyatakan kurang setuju.
\end{abstract}

Kata kunci: Persepsi masyarakat, peranan Sekretaris Desa

\section{PENDAHULUAN}

UU No. 6 tahun 2014 tentang Desa, mengisyaratkan bahwa desa mempunyai kewenangan untuk mengatur dan mengurus sendiri urusan pemerintahan dan kepentingan masyarakat. Dalam rangka melaksanakan urusan pemerintahan yang menjadi kewenangan desa dan untuk peningkatan pembangunan dan pelayanan serta pemberdayaan masyarakat, membutuhkan kemampuan dan kreatifitas para kepala desa dan perangkat desa untuk dapat mengolah sumber-sumber pendapatan desa dan kemudian digunakan secara maksimal untuk pembangunan masyarakat desa setempat.

Sekretaris Desa dipimpin oleh seorang Sekretaris yang berada dan bertanggung jawab langsung kepada Kepala Desa. Sekretaris Desa adalah Perangkat Desa yang membantu Kepala Desa dalam bidang tertib administrasi Pemerintahan dan pembangunan serta pelayanan dan pemberdayaan masyarakat. Untuk dapat menjalankan perannya secara efektif dan efesien, Pemerintah Desa perlu terus dikembangkan sesuai dengan perkembangan kemajuan masyarakat Desa dan lingkungan sekitarnya. Dengan kata lain, perubahan sosial yang terjadi pada masyarakat Desa karena adanya gerakan.

Jalaluddin Rahmat (1998), persepsi adalah pengalaman tentang objek, wisata atau hubungan -hubungan yang diperoleh dengan menyimpulkan informasi dan pesan. Informasi dan tanggapan adalah proses mental yang terjadi pada diri manusia yang akan menunjukkan bagaimana kita melihat, mendengar, merasakan, memberi, serta meraba (Kerja indra) disekitar kita."

Manusia satu yang bersatu dengan manusia lainnya dalam suatu wilayah tertentu akan membentuk sebuah masyarakat. Manusia adalah makhluk sosial (homo socius) yang selalu berhubungan satu dengan yang lain untuk memenuhi kebutuhan hidupnya. Pengertian Masyarakat yang diungkapkan oleh Abdul syani (2007). Kata masyarakat berasal dari musyarak (arab), yang artinya bersama-sama, kemudian berubah menjadi masyarakat, yang artinya berkumpul bersama,hidup bersama saling berhubungan dan saling mempengaruhi, selanjutnya mendapatkan 
Jurnal Sosial Humaniora Sigli (JSH)

p ISSN : 2615-3688

$e$ ISSN : 2716-0270

http://journal.unigha.ac.id/index.php/JSH

kesepakatan menjadi masyarakat (Indonesia). Straubhar menyatakan bahwa masyarakat informasi adalah masyarakat mempunyai aktivitas ekonomi politik-sosial melalui proses produksi, konsumsi dan distribusi informasi(Eka \& Wuryanta, 2013)

Menurut Hasyimi Ali (2002) menjelaskan: Peranan adalah perilaku yang berlangsung atau tindakan yang berkaitan dengan kedudukan tertentu dalam sturuktur organisasi". Istilah peranan dipakai untuk menunjukan gabungan pola-pola kebudayaan yang berkaitan dengan posisi status tertentu. Peranan itu meliputi sikap, nilai, dan perilaku yang ditentukan masyarakat kepada setiap dan semua orang yang menduduki jabatan tertentu. Keterlibatan dapat berupa keterlibatan mental dan emosional serta fisik dalam menggunakan segala kemampuan yang dimilikinya (berinisiatif) dalam segala kegiatan yang dilaksanakan serta mendukung pencapaian tujuan dan tanggung jawab atas segala keterlibatan.(Khalimah, 2016).

Soewarno Handayaningrat dalam bukunya Pengantar Studi Ilmu Administrasi dan Manajemen (2002). Administrasi dalam arti luas yaitu : Leonard D. White dalam bukunya Introduction to The Study of Public Administration mengatakan : Administration is a process common to all group effort, public or private, civil or military, large scale or small scale etc. (Administrasi adalah suatu proses yang pada umumnya terdapat pada semua usaha kelompok, negara, swasta, sipil, atau militer, usaha besar atau kecil, dan sebagainya).

Berdasarkan pengamatan penulis keadaan yang terjadi dilapangan adapun gejala yang nampak dalam proses kinerja pelayanan administrasi karena belum optimalnya kinerja pelayanan yang dilakukan oleh pegawai kantor desa. Hal ini bisa dilihat pada saat pengurusan surat-surat Kartu Keluarga (KK) dan Kartu Tanda Penduduk (KTP) yang diperlukan oleh masyarakat dalam pelayanan administrasi yang diberikan masih belum efektif dan efisien, karena dipengaruhi oleh kemudahan akses sehingga memerlukan waktu yang lama. Selain itu juga Sekretaris Desa yang merangkap jabatan untuk menangani pekerjaan pegawai lainnya. Adapun yang bergerak dalam administrasi pelayanan menunjukan ketidak efektifan dalam memberikan pelayanan dikarenakan prilaku aparat Desa Buntu Awo Kabupaten Luwu yang tidak disiplin dengan tidak tepat waktu masuk dan pulang kerja kantor. Seperti yang diketahui aparat Desa Buntu Awo Kabupaten Luwu seringkali masuk kerja pada siang hari dan pulang kerja tidak pada jam pulang Kantor, sehingga beberapa masyarakat yang ingin mengurus keperluan administrasi tidak mendapatkan aparat Desa yang bertugas. Kemudian proses administrasi pelayanan yang berlangsung membutuhkan waktu lebih dari 1 (satu) hari bahkan lebih.. Selain itu keadaan geografis yang sulit dijangkau karena kantor dinas kependudukan lumayan jauh dari Desa Buntu Awo Kabupaten Luwu sehingga membutuhkan biaya yang lebih apabila ingin pengurusan lebih cepat.

Berdasarkan Hasil Observasi, tersebut terlihat bahwa belum maksimalnya pelayanan publik yang yang diberikan aparatur desa kepada masyarakat selama ini,oleh karena itu penelitian ini sangat penting mengingat bagaimana kualitas pelayanan administrasi yang ada di Desa Buntu Awo Kabupaten Luwu ini masih rendah dan belum tepat cara meningkatkannya. Oleh karena itu, peneliti berkeinginan melakukan penelitian yang berjudul Persepsi Masyarakat Terhadap Faktor Pendukung Sekretaris Desa Dalam Memberikan Pelayanan Di Bidang Administrasi Di Desa Buntu Awo Kabupaten Luwu.

\section{METODE PENELITIAN}

Jenis riset yang digunakan yaitu menggunakan penelitian kuantitatif dimana proses penggalian informasi diwujudkan 
Jurnal Sosial Humaniora Sigli (JSH)

p ISSN : 2615-3688

$e$ ISSN : 2716-0270

http://journal.unigha.ac.id/index.php/JSH

dalam bentuk angka-angka sebagai alat untuk menemukanketerangan mengenai apa yang diketahui, Penelitian ini dilaksanakan di Desa Buntu Awo Kabupaten Luwu Kecamatan Walenrang Utara Kabupaten Luwu. Penelitian ini dilaksanakan pada bulan Maret sampai dengan April 2019. Populasi penelitian ini adalah seluruh masyarakat yang ada di Desa Buntu Awo Kabupaten Luwu sebanyak 300 orang. Sampel pada penelitian ini adalah warga Desa Buntu Awo Kabupaten Luwu yang berjumlah 30 orang, yang diambil menggunakan simple random sampling sebanyak $10 \%$ dari jumlah populasi yang ada. Tekhnik Pengumpulan Data Observasi (Observation), Kuesioner/Angket,

Dokumentasi (Documentation),

Teknik Analisis Data Analisis data menggunakan program komputer Package for Social Science (SPSS).

\section{HASIL PENELITIAN}

Faktor yang Mendukung

Berdasarkan hasil penelitian menunjukkan bahwa faktor yang yang mendukung peranan sekretaris desa dalam memberikan pelayanan di bidang administrasi di Desa Buntu Awo Kabupaten Luwu berada pada kategori sangat mendukung. Kategori sangat mendukung ini diperoleh dari jumlah rata-rata jawaban responden yang terdiri dari 5 pernyataan tentang faktor yang mendukung, sebagai berikut:

a. Rata-rata responden menyatakan sangat mendukung tentang motivasi kerja yang dimiliki sekretaris desa sangat luar biasa

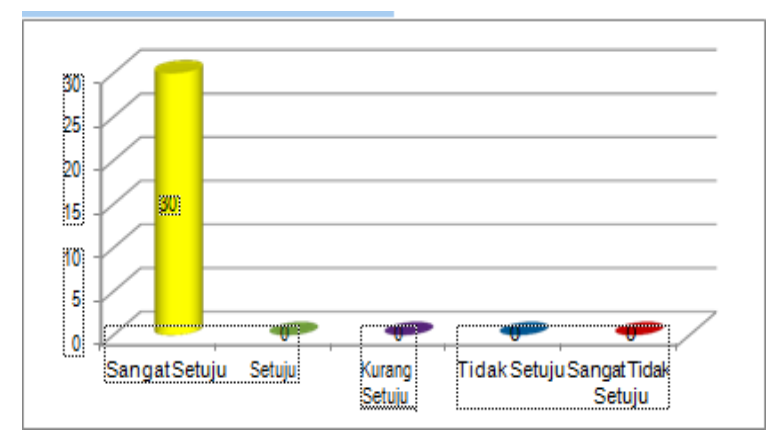

Berdasarkan diagram di atas menunjukkan bahwa sebanyak 30 orang (100\%) menyatakan sangat setuju bahwa motivasi kerja yang dimiliki sekretaris desa sangat luar biasa.

b. Rata-rata responden menyatakan sangat mendukung pengawasan dan kontrol social yang dilakukan sekretaris desa

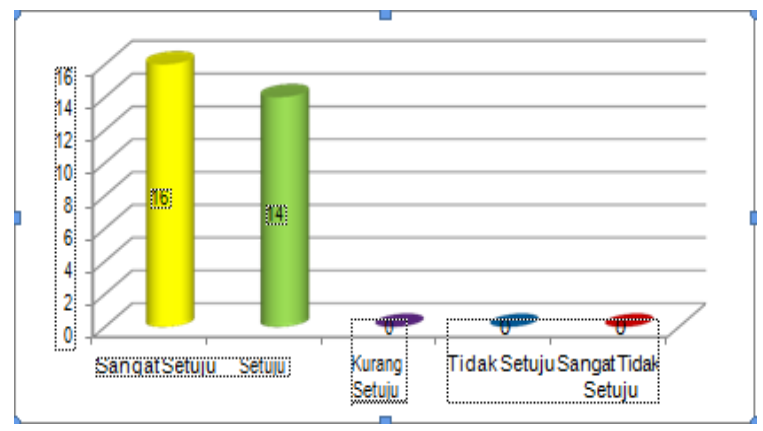

Berdasarkan diagram di atas menunjukkan bahwa sebanyak 16 orang (53\%) sangat setuju dan 14 orang (47\%) menyatakan setuju bahwa pengawasan dan kontrol social yang dilakukan sekretaris desa sudah baik.

c. Rata-rata responden menyatakan mendukung sikap sekretaris desa yang humoris

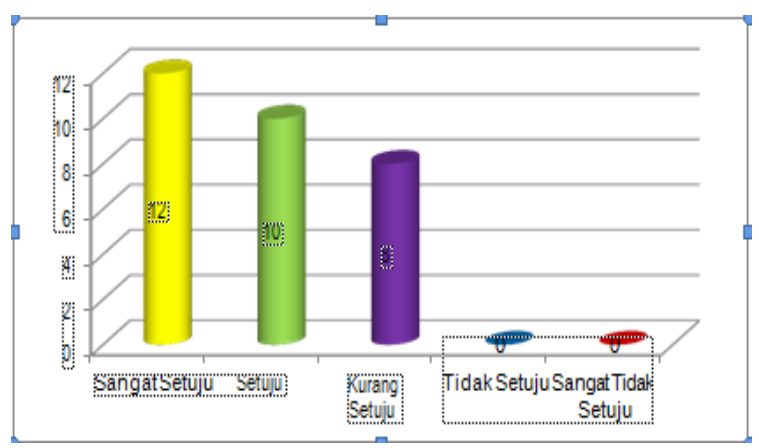

Berdasarkan diagram di atas menunjukkan bahwa sebanyak 12 orang $(40 \%)$ sangat setuju, 10 orang (33\%) setuju dan 8 orang (27\%) menyatakan kurang setuju bahwa sikap sekretaris desa yang humoris.

d. Rata-rata responden menyatakan mendukung kemampuan dan keterampilan yang dimiliki sekretaris 
Jurnal Sosial Humaniora Sigli (JSH)

p ISSN : 2615-3688

$e$ ISSN : 2716-0270

http://journal.unigha.ac.id/index.php/JSH

desa dalam memberikan pelayanan sangat baik.

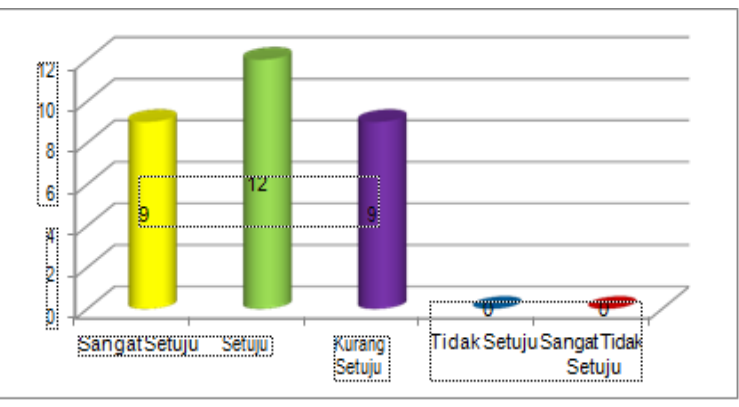

Berdasarkan diagram di atas menunjukkan bahwa sebanyak 9 orang (30\%) sangat setuju, 12 orang $(40 \%)$ setuju dan 9 orang $(30 \%)$ menyatakan kurang setuju bahwa kemampuan dan keterampilan yang dimiliki sekretaris desa dalam memberikan pelayanan sangat baik.

e. Rata-rata responden menyatakan sangat mendukung sikap saling membantu antara sekretaris desa dengan pegawai lainnya

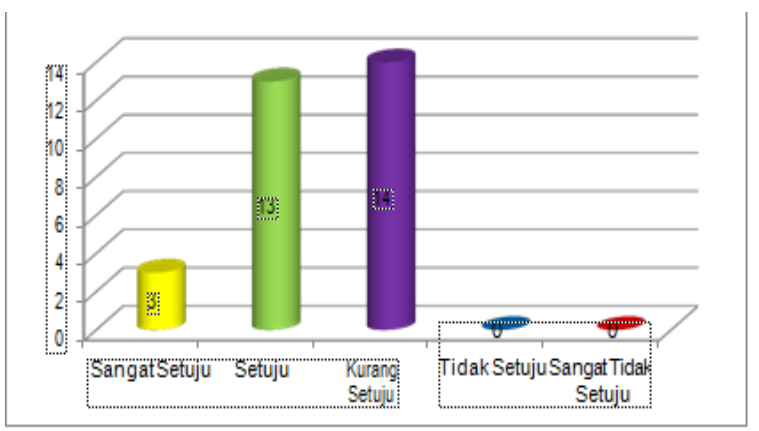

Berdasarkan diagram di atas menunjukkan bahwa sebanyak 3 orang $(10 \%)$ sangat setuju, 13 orang (43\%) setuju dan 14 orang (47\%) menyatakan kurang setuju tentang sikap saling membantu antara sekretaris desa dengan pegawai lainnya.

\section{KESIMPULAN}

Berdasarkan hasil penelitian dan pembahasan sebagaimana diuraikan terdahulu, kesimpulan yang dapat dikemukakan yaitu: Faktor yang yang mendukung peranan Sekretaris Desa dalam memberikan pelayanan di bidang administrasi di Desa Buntu Awo Kabupaten Luwu berada pada kategori sangat mendukung. Faktor-faktor yang mendukung tersebut, antara lain: motivasi kerja yang dimiliki Sekretaris Desa sangat luar biasa, pengawasan dan kontrol social yang dilakukan Sekretaris Desa, sikap Sekretaris Desa yang humoris, kemampuan dan keterampilan yang dimiliki Sekretaris Desa dalam memberikan pelayanan sangat baik dan sikap saling membantu antara sekretaris desa dengan pegawai lainnya. Hal ini terlihat dari jawaban responden sebanyak $45,3 \%$ menyatakan sangat setuju, 34\% setuju dan sebanyak $20,7 \%$ menyatakan kurang setuju.

\section{DAFTAR PUSTAKA}

Ali, Hasyimi. 2002. Organisasi dan Manajemen. Bumi Aksara. Jakarta. Hariyono, Paulus. 2007. Sosiologi Kota untuk Arsitek. Bumi Aksara. Jakarta.

Drs.Jalaluddin Rakhmat, M.SC .Psikologi Komunikasi :Penerbit PT Remaja Rosdakarya : Bandung.

Eka, A. G., \& Wuryanta, W. (2013). Digitalisasi Masyarakat: Menilik Kekuatan dan Kelemahan Dinamika Era Informasi Digital dan Masyarakat Informasi. Jurnal Ilmu Komunikasi, 131-142.

Khalimah. (2016). Partisipasi masyarakat Dusun Kalipucung dalam kebijakan sekolah satu atap di SMPN 4 Salaman [Participation of Dusun Kalipucung villagers in one-roof school policy in SMPN 4 Salaman]. Jurnal Kebijakan Pendidikan, 5(4), 384-394.

http://journal.student.uny.ac.id/ojs/index.ph $\mathrm{p} / \mathrm{sakp} / \mathrm{article} / \mathrm{view} / 5239$

https://guruakuntansi.co.id/pengertianadministrasi/ 
Jurnal Sosial Humaniora Sigli (JSH)

p ISSN : 2615-3688

$e$ ISSN : 2716-0270

http://journal.unigha.ac.id/index.php/JSH

Rahmat, Djalaludin 2009. Teori dan Praktek

UURI 22/1999. Undang-Undang Republik Kepemimpinan. Rineka Cipta. Jakarta. Indonesia No. 22 Tahun 1999 Tentang Pemerintahan Daerah. 2002. Jakarta: Biro Humas Depdagri.

Sani, Adbul. 2017. Dasar - Dasar Kebijakan Publik. Alfabeta. Bandung. Sugiono. 2017. Metode Penelitian Kuantitatif dan Kualitatif. Alfabeta. Bandung.

Soekanto, Soeryono. 2005. Sosiologi Suatu Pengantar. Raja Grafindo Persada. Yogyakarta.

UURI 32/2004. Undang-Undang Nomor 32 Tahun 2004 Tentang Otonomi Daerah. 2010. Jakarta: Rajawali Press.

https://www.gurupendidikan.co.id/peng ertian-persepsi/

Sukanto, Sujono. 2009. Dasar-Dasar Kebijakan Publik dan Analisis Kebijakan. Ombak. Yogyakarta. 